\title{
Outcomes of Patients with Parkinson Disease and Pathological Gambling
}

\author{
A. Bharmal, C. Lu, J. Quickfall, D. Crockford, O. Suchowersky
}

\begin{abstract}
Objective: To determine the outcomes of patients with Parkinson disease (PD) with pathological gambling (PG) from one Canadian Movement Disorders Clinic. Methods: Assessments were performed in-person during routine clinic visits of all patients currently followed by one neurologist (OS). Pathological gambling was defined according to DSM-IV-TR criteria. Chart review was performed to obtain details on medication use, dosages, and patient demographics. Follow-up of patients with PG collected information on gambling behavior, PG management interventions, medications, treatment, and psychosocial outcomes. Results: 146 patients were surveyed with an overall prevalence of PG of $4.1 \%$ (6/146). The rate of pathological gambling for those patients on dopamine agonist therapy (DA) was $8.1 \%$ (6/74). Only patients who were recreational gamblers prior to starting DA developed PG. All PG patients discontinued, decreased, or switched to another DA, and experienced a partial or full remission of PG. 3 (50\%) patients described financial losses of $\$ 100,000$ or more, and 75\% (3/4) patients described significant marital stresses. At follow-up (August 2008), 4 of the 6 patients with PG continued to gamble in a controlled fashion despite medication changes. No significant difference in levodopa equivalent daily dose (LEDD) pre- and post-PG were observed; however, the relative amount of DA was decreased ( $\mathrm{p}=0.0593)$, while levodopa was relatively increased $(\mathrm{p}=0.5277)$. Despite control of $\mathrm{PG}$, patients still experience financial and marital strains. Conclusions: DA (in combination with levodopa) was associated with a significantly higher prevalence of PG in PD, particularly in patients who were recreational gamblers previously. Despite control of PG, patients continued to experience significant financial and marital stresses that should be regularly enquired upon in follow-up care and managed appropriately.
\end{abstract}

RÉSUMÉ: Prévalence et évolution du jeu pathologique chez des patients atteints de la maladie de Parkinson. Objectif : Le but de l'étude était d'étudier l'évolution de patients atteints de la maladie de Parkinson (MP) qui sont des joueurs pathologiques dans une clinique canadienne de désordres du mouvement. Méthodes : Nous avons réalisé des évaluations pendant des visites de routine à la clinique chez tous les patients suivis régulièrement par le même neurologue (OS). Le jeu pathologique (JP) était défini selon les critères du DSM-IV-TR. Nous avons effectué une revue de dossiers pour recueillir les données démographiques, la prise de médicaments et les doses des médicaments. Au cours du suivi des patients présentant du JP, nous avons colligé les données suivantes : les habitudes de jeux, les interventions pour la gestion du JP, la médication, le traitement et les conséquences psychosociales du JP. Résultats : Cent quarante-six patients ont participé à l'enquête et la prévalence du JP était de 4,1\% (6/146). Le taux de jeux pathologique chez les patients qui prenaient un agoniste de la dopamine (AD) était de 8,1\% (6/74). Seuls les patients qui étaient des joueurs récréatifs avant le début de l'AD ont présenté du JP. Tous les joueurs pathologiques ont cessé, diminué ou changé d'AD et ont eu une rémission partielle ou totale du JP. Trois (50\%) des patients ont rapporté des pertes financières de $\$ 100000$ ou plus et $75 \%$ (3/4) ont décrit des tensions conjugales importantes. Au moment du suivi en août 2008, 4 des 6 patients qui présentaient du JP continuaient à jouer de façon contrôlée malgré le changement de médication. Nous n'avons pas observé de différence significative de la dose quotidienne équivalente de lévodopa avant et après le JP. Cependant, la quantité relative d'AD était diminuée $(\mathrm{p}=0,0593)$ et la lévodopa relativement augmentée $(\mathrm{p}=0,5277)$. Malgré le contrôle du JP, les patients éprouvaient toujours des tensions financières et conjugales. Conclusions : L'AD, en combinaison avec la lévodopa, était associé à une prévalence significativement plus élevée de JP chez les patients atteints de la MP, surtout chez ceux qui étaient des joueurs récréatifs antérieurement. Malgré le contrôle du JP, les patients continuent à éprouver des tensions financières et conjugales dont on devrait s'informer au cours du suivi et qu'on devrait traiter adéquatement.

Can. J. Neurol. Sci. 2010; 37: 473-477

Multiple reports have described the development of pathological gambling (PG) in patients treated for Parkinson Disease (PD) with dopamine replacement therapy, particularly dopamine agonists (DA) ${ }^{1-9}$. Although rates vary due to methodological differences, particularly with regards to sampling methods and time frames, the prevalence of PG in treated PD patients has been reported to be between 2.6-6.1\% The prevalence of PG in those treated with DA has been estimated between $8-12 \%^{10,11}$; the estimated prevalence of PG in the general population of the United States and Canada is 1-
$2 \%{ }^{12-14}$. In previous reports, only patients with a prior history of gambling have developed $\mathrm{PG}^{8}$.

\footnotetext{
From the Department of Clinical Neurosciences (AB, CL, OS), Department of Psychiatry (JQ, DC), Foothills Hospital Addiction Centre (DC), Department of Medical Genetics (OS), University of Calgary, Calgary, Alberta, Canada. Received June 30, 2009. Final Revisions Submitted February 2, 2010. Correspondence to: Oksana Suchowersky, Department of Medical Genetics, Area 3, UCMC, 3350 Hospital Drive NW, Calgary, Alberta, T2N 4N1, Canada.
} 
Though prevalence data is available, there is a paucity of literature on the treatment outcomes of PD patients with PG attributed to DA therapy. Once established, addictive behaviours like PG and their consequences often persist with ongoing vulnerability to relapse despite the underlying initiating factors being removed ${ }^{15-21}$. Although previous reports have suggested that PG can be controlled through discontinuation of DA therapy, switching to another DA, or lowering the dose of a current $\mathrm{DA}^{6,22-24}$, only one study ${ }^{24}$ has assessed the treatment outcomes of patients with $\mathrm{PG}$. No information regarding the relative efficacy of various management strategies for PG in PD has been presented to date and the psychosocial sequelae of $\mathrm{PG}$ attributable to DA therapy in PD patients, particularly relating to marital and financial stresses, has been poorly described. The current study was initially undertaken to evaluate the prevalence of PG in patients treated for $\mathrm{PD}^{25}$. Patients identified with PG were then followed prospectively to describe the outcome of their PD and PG when their DA treatment was altered. The sequelae of changes to DA treatment were also evaluated.

\section{Methods}

Since 2005 all idiopathic PD patients with PG followed by one neurologist (OS) were identified as they came into clinic. Patients were diagnosed with PD according to the UK Brain Bank Criteria ${ }^{26}$, and patients with dementia were excluded. Gambling behavior was identified and assessed through routine questioning on type and frequency of gambling and whether strains were experienced from gambling. 'Recreational gamblers' were defined as those patients who described their gambling as infrequent with no gambling-related financial or relational strains. All patients diagnosed with PG met DSM-IV$\mathrm{TR}^{15}$ criteria. Results of this review were previously published ${ }^{25}$.

Patients identified with PG were prospectively followed from July 2005 to June 2008 through clinical follow-up visits at the Movement Disorders Clinic and/or the Foothills Hospital Addiction Centre, where information on outcomes of PG was collected. Clinical follow-up of patients with PG assessed the efficacy of management strategies for PG, the outcomes of these treatment strategies, as well as the psychosocial sequelae of those patients with PG. Pathological gambling behavior, including the onset of PG, extent of losses, interventions for PG control and their effectiveness, as well as psychosocial sequelae, including relational and financial stresses, were queried.

Information regarding control of finances during PG was collected from family members/caregivers or patients directly during follow-up. Background information gathered via chart review included patient age, sex, disease duration, DA use history, and PD history.

\section{ANALYSIS}

Data processing and analysis was performed using STATA Version 9.0. A one-sample test of proportions was completed to compare the prevalence of PG among the study population with the general Alberta population ${ }^{14}$. Using a test for independent proportions, the PD population was stratified into males and females, and the rate of PG was compared.

To determine if there were age differences among the PG and the PD population, or if there was a difference in disease duration between the two groups, an independent t-test was utilized. In order to decipher if prevalence of PG between patients on levodopa monotherapy versus patients on dopamine agonists was different, a test for independent proportions was executed. Using a Pearson chi-squared test with Yates' correction of continuity, the rate of PG was compared among all four dopamine agonists.

The Wilcoxon Signed Rank Test was used to determine whether the medication use of patients with PG was significantly different following interventions for PG control than when PG was first noted clinically.

Efficacy of medications in PG patients was determined through calculation of a levodopa-equivalent daily dose (LEDD) based on the following formula, which has been previously reported $^{8,27}: 100 \mathrm{mg}$ of levodopa $=130 \mathrm{mg}$ of controlled-release levodopa $=70 \mathrm{mg}$ of levodopa + catechol-O-methyl transferase inhibitor $=1 \mathrm{mg}$ of pergolide $=1 \mathrm{mg}$ of pramipexole $=5 \mathrm{mg}$ of ropinirole $=10 \mathrm{mg}$ of bromocriptine. Significance was set at $\mathrm{p}=$ 0.05 .

\section{RESULTS}

We initially reported on 198 PD patients followed at the Movement Disorders Clinic ${ }^{25}$. Thirty-nine patients were excluded as they had surgery for PD and will be reported on separately and 13 further patients were excluded due to dementia, recent death, or relocation to another city/town. Of the 146 remaining patients where long-term follow-up could be obtained, the overall prevalence of PG was $4.1 \%$ (6/146). When compared to the $1.3 \%$ prevalence of PG in the general Alberta population ${ }^{14}$, this observed increased prevalence was statistically significant $(\mathrm{p}=0.0152)$.

Demographics and disease-specific information are provided in Table 1. At the onset of PG, the mean age of the patients was 55 years $(\mathrm{sd}=8.2)$ and the mean duration of PD from the time of diagnosis was 7.5 years $(s d=5.8)$. Of the six identified patients, two were female. The PG patient group was significantly younger than the PD population $(58 \pm 6.74$ yrs vs. $68 \pm 10.4$ yrs, $\mathrm{p}=0.0198)$. There was no significant difference in disease duration between the PG group and the general PD population $(\mathrm{p}=0.0918)$.

Table 1: Demographic and Parkinson Disease specific information of patients

\begin{tabular}{l|c|c|c}
\hline & $\begin{array}{c}\text { Number } \\
\text { of } \\
\text { Patients }\end{array}$ & $\begin{array}{c}\text { Mean Age } \\
(\mathbf{y} \pm \mathbf{S D})\end{array}$ & $\begin{array}{c}\text { Mean } \\
\text { Duration of } \\
\text { PD (y+ SD) }\end{array}$ \\
\hline Total Males & 99 & $67 \pm 10.2^{\mathbf{a}}$ & $9 \pm 6.8$ \\
\hline $\begin{array}{l}\text { Total } \\
\text { Females }\end{array}$ & 47 & $71 \pm 10.3^{\mathbf{a}}$ & $10 \pm 5.3$ \\
\hline PG Males & 4 & $57 \pm 7.7^{\mathbf{b}}$ & $11 \pm 7.4$ \\
\hline PG Females & 2 & $62 \pm 4.2^{\mathbf{b}}$ & $12 \pm 0.7$ \\
\hline
\end{tabular}

PD - Parkinson Disease, PG - pathological gambling, y - years, SD standard deviation. Mean age of total PD group ${ }^{\mathrm{a}}$ significantly greater $(\mathrm{p}<0.001)$ than PG group ${ }^{\mathrm{b}}$. 
Table 2: Prevalence rates of pathological gambling in PD patients on dopamine replacement therapy

\begin{tabular}{l|l|l|l|l}
\hline $\begin{array}{l}\text { Medication/ } \\
\text { Treatment }\end{array}$ & $\begin{array}{l}\text { Number of } \\
\text { Patients }\end{array}$ & $\begin{array}{l}\text { Number of } \\
\text { Recreational } \\
\text { Gamblers } \\
\text { (Prevalence \%) }\end{array}$ & $\begin{array}{l}\text { Number of } \\
\text { Pathological } \\
\text { Gamblers } \\
\text { (Prevalence \%) }\end{array}$ & $\begin{array}{l}\text { Mean } \\
\text { Medication } \\
\text { Dose (mg/d) }\end{array}$ \\
\hline Levodopa alone & 80 & $10(13)$ & 0 & 665 \\
\hline Pramipexole & 41 & $14(34)$ & $5(12.2)^{*}$ & 3.3 \\
\hline Pergolide & 11 & $1(9)$ & $1(9.1)^{*}$ & 5.1 \\
\hline Ropinirole & 9 & $3(33)$ & $0(0)^{*}$ & 14 \\
\hline Bromocriptine & 5 & $0(0)$ & $0(0)^{*}$ & 22.7 \\
\hline & 146 & 28 & $6(4)$ & \\
\hline
\end{tabular}

* Non-significant difference in PG risk among DA; Only patients who were recreational gamblers prior to starting dopamine replacement therapy developed PG.

Twenty eight of 146 (19.1\%) patients were infrequent or "recreational" gamblers before starting treatment. Patients who did not gamble prior to treatment did not develop PG with medication (Table 2). None of the patients on levodopa monotherapy developed PG. There was a statistically significant difference in prevalence of PG between patients on levodopa monotherapy versus patients on DA $(p<0.01)$. Of the PD patients on levodopa and DA combination therapy, the prevalence of PG was $8 \%(6 / 74)$.

All three commonly used DA appeared to be associated with PG. No patients on bromocriptine developed PG. No patients with PG on DA monotherapy were identified. Pathological gambling onset did not start upon initiation of DA treatment, but tended to begin once the drug was titrated to a clinically effective dose.

Treatment of PG varied among the patients and included changing from one DA to another, lowering the DA dose, discontinuation of the DA, counseling, and/or participation in support groups. One of the six patients (Patient 6) exhibited PG on more than one agonist (pergolide and ropinirole) (Table 3). The other five patients developed PG from only one agonist with resolution once they switched to another DA or the DA was discontinued.

Table 3 describes gambling behavior following changes to DA therapy. Despite control of PG following a switch from pramipexole to ropinirole, one patient (Patient 3) opted to continue on pramipexole as ropinirole provided little motor benefit, and she did not feel 'as good' on it. She remains on a lower dose of pramipexole, and continues to experience gambling urges, but has transferred control of finances to her husband. Another patient (Patient 6) showed PG behavior even after being switched from pergolide to ropinirole. He remains on ropinirole, and controls his gambling through self-control, and by abstaining from visiting casinos. Two patients (Patients 1 and 5) discontinued DA altogether as they could not tolerate/received little motor benefit from other DA. Tapering of DA was only performed in one patient (Patient 2), and was found to be ineffective in controlling PG. Once this patient's DA was switched from pramipexole to ropinirole, gambling behavior came under control.

Gambling behavior improved or disappeared in all six patients. Two patients (33\%) (Patients 3 and 6) described a continued, but controllable, urge to gamble following treatment. At follow-up, four of the six patients $(67 \%)$ continued to gamble, but in a subjectively occasional or controlled fashion. To thwart PG behavior, family members and caregivers limited access to money in most cases.

The mean DA doses at the time when PG was initially identified and at the end of the follow-up period (June 2008) are reported in Table 3. Patients received relatively lower DA and higher levodopa dosages at follow-up, but neither of these differences were statistically significant $(\mathrm{p}=0.0593$ and 0.5277 , respectively). The LEDD of patients when $\mathrm{PG}$ was first identified clinically and at follow-up, an average of 33 months $(\mathrm{sd}=13.5)$, was also not found to be significantly different $(\mathrm{p}=0.9084)$.

Pathological gambling patients experienced substantial financial and marital stress, even after control of PG. Five (83\%) patients described financial losses that they felt had caused them significant distress; three $(50 \%)$ patients experienced losses of over $\$ 100,000$. One patient was forced to re-mortgage his house and needed to borrow money from family members. Of the four $(67 \%)$ patients who were married, all remained married, but three described marked marital stress related to their PG even following changes in DA treatment. Over the course of their PG and even after reduction or cessation of their gambling, spouses were less trusting of the patients' behavior, and blamed them for the financial stresses they experienced. One patient attended regular marriage counseling sessions with her husband following group cognitive behavioral therapy for PG.

\section{Discussion}

Dopamine agonists therapy (in combination with levodopa) has been found to be associated with an increased prevalence of $\mathrm{PG}$ in $\mathrm{PD}^{1-10,24}$, particularly in younger patients $\mathrm{s}^{6,8,10,24}$. Of the current study's sample of 146 treated PD patients, a PG prevalence of $4.1 \%$ was found. This finding is consistent with previous reports ${ }^{6-8,10,11}$ and statistically significantly greater $(\mathrm{p}=$ 0.0152 ) than the rate of $P G$ in the general population ${ }^{12-14}$. An overall PG prevalence of $8.1 \%$ (6/74) for all patients treated with a DA was also observed with no one DA imparting an observed greater risk than another.

Similar to results of Mamikonyan and colleagues ${ }^{24}$, all patients who had their DA discontinued or changed upon identification of their PG had a partial or full-remission of PG at follow-up, despite LEDD remaining not statistically different. These observations may be interpreted to suggest that DA exposure contributes to the development and persistence of PG, but it is recognized that changes in gambling behavior are inherently less predictable than other addictive behaviors. Changes in gambling behavior may be related to the problems caused by the gambling itself or natural remission rather than alterations in the medication regimen ${ }^{28,29}$.

Some patients with PG were reluctant to discontinue DA because of the perceived benefits of therapy. Patients' subjectively assessed their motor performance as poorer when switched to another, when they discontinued DA, or lowered the dose of DA. As no PG was observed on levodopa alone in our sample, discontinuation of DA while increasing levodopa was helpful in several of the patients. In others, due to poor control of 
Table 3: Long-term outcomes and psychosocial sequelae of patients with PG

\begin{tabular}{|c|c|c|c|c|c|c|c|c|c|}
\hline \multirow[b]{2}{*}{ Patient } & \multirow[b]{2}{*}{$\begin{array}{l}\text { Duration } \\
\text { of } P D \\
\text { (years) }\end{array}$} & \multicolumn{4}{|c|}{ Time of gambling } & \multicolumn{4}{|c|}{ Time 2-August 2008} \\
\hline & & $\begin{array}{l}\text { Dopamine } \\
\text { agonist used } \\
\text { and dose } \\
(m g / \text { day })\end{array}$ & $L E D D$ & $\begin{array}{l}\text { Intervention(s) } \\
(D A \mathrm{mg} / \text { day })\end{array}$ & $\begin{array}{l}\text { Outcome (patient } \\
\text { reported) }\end{array}$ & $\begin{array}{l}\text { Evidence of } \\
\text { gambling? }\end{array}$ & $\begin{array}{l}\text { Dopamine } \\
\text { agonist used and } \\
\text { dose (mg/day) }\end{array}$ & $L E D D$ & Psychosocial sequelae \\
\hline 1 & 12 & $\begin{array}{l}\text { Pramipexole } \\
(4.5)\end{array}$ & 911.53 & $\begin{array}{l}\text { 1. Switched to ropinirole }(15) \text { - no gambling but } \\
\text { little motor benefit } \\
\text { 2. DA stopped altogether } \\
\text { 3. Psychiatrist consult } \\
\text { 4. Re-started SSRI }\end{array}$ & Full remission & No & None & 879.12 & $\begin{array}{l}\text { Financial losses of } \\
\text { approximately } \$ 100,000 ; \\
\text { Significant marital strain }\end{array}$ \\
\hline 2 & 23 & $\begin{array}{l}\text { Pramipexole } \\
\text { (6) }\end{array}$ & 2105.49 & $\begin{array}{l}\text { 1. Pramipexole tapered (3.75) - continued PG } \\
\text { 2. Switched to pergolide }(2)-\text { controlled } \\
\text { gambling but little motor benefit } \\
\text { 3. Switched to ropinirole }(10) \text { - controlled } \\
\text { gambling with better motor control } \\
\text { 4. Attended gamblers anonymous } \\
\text { 5. Psychiatrist consult }\end{array}$ & $\begin{array}{l}\text { Not gambling } \\
\text { excessively }\end{array}$ & $\begin{array}{l}\text { Occasional } \\
\text { controlled } \\
\text { gambling }\end{array}$ & Ropinirole (10) & 1603.85 & $\begin{array}{l}\text { Financial losses of } \$ 3000 \text {; } \\
\text { Strain on marriage }\end{array}$ \\
\hline 3 & 13 & $\begin{array}{l}\text { Pramipexole } \\
(4.5)\end{array}$ & 1103.85 & $\begin{array}{l}\text { 1. Switched to ropinirole }(20)-\text { controlled } \\
\text { gambling but little motor benefit } \\
\text { 2. Pramipexole re-started ( } 4.5) \text { despite increased } \\
\text { risk of gambling } \\
\text { 3. Spouse took control of finances }\end{array}$ & $\begin{array}{l}\text { Gambling urge } \\
\text { present }\end{array}$ & $\begin{array}{l}\text { Yes, but } \\
\text { finances } \\
\text { controlled }\end{array}$ & $\begin{array}{l}\text { Pramipexole } \\
(1.5 \mathrm{mg})^{1}\end{array}$ & 1103.85 & None \\
\hline 4 & 9 & $\begin{array}{l}\text { Pramipexole } \\
(1.5)\end{array}$ & 457.69 & $\begin{array}{l}\text { 1. Switched to ropinirole (15) - no gambling } \\
\text { with good motor benefit }\end{array}$ & Full remission & No & $\begin{array}{l}\text { Ropinirole } \\
(15 \mathrm{mg})\end{array}$ & 607.69 & Financial losses of $\$ 20,000$ \\
\hline 5 & 9 & $\begin{array}{l}\text { Pramipexole } \\
\text { (7.5) }\end{array}$ & 2178.57 & $\begin{array}{l}\text { 1. Pramipexole discontinued } \\
\text { 2. Attended gamblers anonymous } \\
\text { 3. Psychiatrist consult }\end{array}$ & Full remission & $\begin{array}{l}\text { Occasional } \\
\text { controlled } \\
\text { gambling }\end{array}$ & None & 1714.29 & $\begin{array}{l}\text { Strain on marriage, six- } \\
\text { figure financial losses }\end{array}$ \\
\hline 6 & 6 & Pergolide (3) & 600 & $\begin{array}{l}\text { 1.Abstained from visiting casinos } \\
\text { 2. Psychiatrist consult }\end{array}$ & $\begin{array}{l}\text { Partial remission } \\
\text { (through } \\
\text { abstinence) but } \\
\text { still an urge to } \\
\text { gamble }\end{array}$ & $\begin{array}{l}\text { Occasional } \\
\text { controlled } \\
\text { gambling }\end{array}$ & Ropinirole* (15) & 1200 & $\begin{array}{l}\text { Financial losses of over } \\
\$ 100,000 \text {; borrowed } \\
\text { money from family } \\
\text { members; re-mortgaged } \\
\text { house }\end{array}$ \\
\hline
\end{tabular}

${ }^{1}$ Patient resumed pathologically gambling on higher dose, and was subsequently kept on a very low dose of pramipexole (1.5 mg/day).

* Patient switched from pergolide to ropinirole due to pergolide's risk of causing valvular damage, rather than as a gambling intervention.

motor symptoms with discontinuation of the DA, substitution of another DA resulted in improved motor control without recurrence of gambling behavior. In a minority of patients, the same DA needs to be restarted but kept at a lower dose. Thus, treatment needs to be individualized for each patient. In contrast to previous reports suggesting motor control is relatively unchanged following DA switching, lowering, or discontinuation $^{24}$, our data suggests that motor performance can be affected adversely despite LEDD maintenance in a minority of patients.

As previously reported $^{8}$, we also found that only those patients who were recreational gamblers prior to initiating DA developed PG. This suggests that pre-morbid non-pathological gambling behavior may confer a potential risk for developing PG upon initiation of a DA and should be screened for early in PD treatment. As such, non-pathological and 'recreational' gamblers should be closely monitored clinically to assess for any change in their gambling behavior as DA may be a contributor.

To our knowledge this is the first study to look at the psychosocial sequelae of PG developing during PD treatment with dopamine replacement therapy. In the patients where PG was identified, substantial marital and financial stress was described even after PG abated. Three $(50 \%)$ of the patients described losses of over $\$ 100,000$ and three out of four $(75 \%)$ of the married patients with PG described their relationship with their spouse was negatively affected in an ongoing fashion by their prior PG. It is well recognized that PG impacts on the family and financial, personal, and vocational endeavors adversely and that the sequelae often have lasting effects even when gambling behavior is addressed ${ }^{15,17-20}$; PD patients with PG face similar psychosocial sequelae that need to be addressed in concert with reviewing their dopamine replacement therapy regimen. The psychosocial consequences related to PG should be sought involving family members or caregivers. Based on the reports of the ongoing loss of trust in their relationships, particularly considering that many of the identified patients continued to gamble (albeit less frequently), abstinence from gambling should be emphasized with specific plans put in place as to how to limit access to funds by patients and engage them in known effective treatments for $\mathrm{PG}^{20,30}$.

There are a number of limitations in our study. No validated screening tools were used to systematically assess patients for PG. Other investigators have used tools such as the South Oaks Gambling Screen $^{31}$ or Minnesota Impulsive Disorders Inventory $^{32}$. However, as all patients met DSM-IV-TR criteria for PG it is likely that this represents an underestimation of prevalence rather than an overestimation. This is not surprising, as one year prevalence rates in other studies have generally been higher than what is presented here, including recent data from our own clinic ${ }^{11}$. In assessing the gambling outcomes of patients in follow-up, we relied on patient and family member assessments of gambling behavior; we did not use similar instruments to assess whether the patient was in full remission from $\mathrm{PG}$.

It is important to note that we did not systematically check for other potentially associated behavioral disturbances but 
discovered these upon patient assessments. These included hypersexuality and other apparent compulsive activities such as shopping, eating, and video game playing. These behaviors and other impulse control disorders (ICD) have been reported to be caused by DA use in $\mathrm{PD}^{4,8,22-24}$. Future work and follow-up should not only assess the treatment outcomes of patients with ICD, but assess the psychosocial sequelae of patients during and after the ICD has purportedly been treated.

\section{CONCLUSION}

Our study identified an increased overall prevalence of PG in the PD population consistent with that previously reported, particularly in PD patients treated with DA. Parkinson disease patients who developed PG all previously reported prior nonpathological gambling involvement. Discontinuation or changing DA was associated with the cessation or reduction of gambling, but patients reported ongoing psychosocial sequelae from their prior PG with regards to their finances and relationships. The findings suggest that gambling behavior should be inquired of before initiating dopamine replacement therapy in order to identify those who may be at higher risk of developing PG and as part of the routine follow-up to determine if problematic gambling is developing. Altering DA therapy if PG develops appears to be helpful, but control of movement disorder symptoms may be reduced, emphasizing that rather than limiting the use of these effective therapies, physicians should inform all patients of the potential risk for developing PG with DA therapy for PD. For those patients who develop PG, management should go beyond altering dopamine replacement therapy, including family or caregivers in treatment plans, and utilizing known effective treatments for PG.

\section{REFERENCES}

1. Dodd ML, Klos KJ, Bower JH, Geda YE, Josephs KA, Ahlskog JE. Pathological gambling caused by drugs used to treat Parkinson Disease. Arch Neurol. 2005;62:1377-81.

2. Avanzi M, Uber E, Bonfa F. Pathological gambling in two patients on dopamine replacement therapy for Parkinson's Disease. Neurol Sci. 2004;25:98-101.

3. Molina JA, Sainz-Artiga MJ, Fraile A, Jiménez-Jiménez FJ, Villanueva C, Ortí-Pareja M, et al. Pathological gambling in Parkinson's disease: a behavioral manifestation of pharmacologic treatment? Mov Disord. 2000;15(5):869-72.

4. Driver-Dunckley E, Samanta J, Stacy M. Pathological gambling associated with dopamine agonist therapy in Parkinson's disease. Neurology. 2003;61(3):422-3.

5. Gschwandtner U, Aston J, Renaud S, Fuhr P. Pathological gambling in patients with Parkinson's Disease. Clin Neuropharm. 2001;24(3):170-2.

6. Voon V, Hassan K, Zurowski M, de Souza M, Thomsen T, Fox S, et al. Prospective prevalence of pathologic gambling and medication association in Parkinson disease. Neurology. 2006;66 (11):1750-2.

7. Avanzi M, Baratti M, Cabrini S, Uber E, Brighetti G, Bonfa F. Prevalence of pathological gambling in patients with Parkinson's disease. Mov Disord. 2006;21(12):2068-72.

8. Weintraub D, Siderowf AD, Potenza MN, Goveas J, Morales KH, Duda JE, et al. Association of dopamine agonist use with impulse control disorders in Parkinson disease. Arch Neurol. 2006;63(7):969-73.

9. Montastruc JL, Schmitt L, Bagheri H. [Pathological gambling behavior in a patient with Parkinson's disease treated with levodopa and bromocriptine]. Rev Neurol (Paris). 2003;159(4): 441-3. French.
10. Grosset KA, Grosset DG, Macphee G, Pal G, Stewart D, Watt A, et al. Problematic gambling on dopamine agonists: not such a rarity. Mov Disord. 2006;21(12):2206-8.

11. Crockford D, Quickfall J, Currie S, Furtado S, Suchowersky O, ElGuebaly N. Prevalence of problem and pathological gambling in Parkinson's disease. J Gambl Stud. 2008;24(4):411-22.

12. Shaffer HJ, Hall MN, Vander Bilt J. Estimating the prevalence of disordered gambling behavior in the United States and Canada: a research synthesis. Am J Public Health. 1999;89(9):1369-76.

13. Volberg RA. The prevalence and demographics of pathological gamblers: implications for public health. Am J Public Health. 1994;84(2):237-41.

14. Smith GJ, Wynne HJ. Measuring gambling and problem gambling in Alberta using the Canadian Problem Gambling Index (CPGI): Alberta Gambling Research Institute, 2002.

15. Association AP. Diagnostic and statistical manual of mental disorders. 4th ed.. Text revision ed. Washington, DC: American Psychiatric Association; 2003.

16. Shaw MC, Forbush KT, Schlinder J, Rosenman E, Black DW. The effect of pathological gambling on families, marriages, and children. CNS Spectr. 2007;12(8):615-22.

17. Hodgins DC, El-Guebaly N. Retrospective and prospective reports of precipitants to relapse in pathological gambling. J Consult Clin Psychol. 2004;72:72-80.

18. Raylu N, Oei TPS. Pathological gambling: a comprehensive review. Clin Psychol Rev. 2002;22(7):1009-61.

19. Oei TPS, Raylu N. Psychosocial factors related to gambling abstinence and relapse in members of Gamblers Anonymous. J Gambl Stud. 2008;24:91-105.

20. Walker, MB. Treatment strategies for problem gambling: a review of effectiveness. In: Eadington WR, Cornelius JA, editors. Gambling behavior and problem gambling. Reno, Nevada: University of Nevada;1993 p. 533-66.

21. Kalivas PW, Volkow ND. The neural basis of addiction: a pathology of motivation and choice. Am J Psychiatry. 2005;162:1403-13.

22. Nirenberg MJ, C Waters. Compulsive eating and weight gain related to dopamine agonist use. Mov Disord. 2006;21(4):524-9.

23. Klos KJ, Bower JH, Josephs KA, Matsumoto JY, Ahlskog JE. Pathological hypersexuality predominantly linked to adjuvant dopamine agonist therapy in Parkinson's disease and multiple system atrophy. Parkinsonism Relat Disord. 2005;11(6):381-6.

24. Mamikonyan E, Siderowf AD, Duda JE, Potenza MN, Horn S, Stern MB, et al. Long-term follow-up of impulse control disorders in Parkinson's disease. Mov Disord. 2008;23(1):75-80.

25. Lu C, Bharmal A, Suchowersky O. Gambling and Parkinson disease. Arch Neurol. 2006;63:298.

26. Hughes AJ, Daniel SE, Kilford L, Lees AJ. Accuracy of clinical diagnosis of idiopathic Parkinson's disease: a clinicopathological study of 100 cases. J Neurol Neurosurg Psychiatry. 1992;55(3): 181-4

27. Hobson DE, Lang AE, Martin WR, Razmy A, Rivest J, Fleming J. Excessive daytime sleepiness and sudden-onset sleep in Parkinson disease: a survey by the Canadian Movement Disorders Group.[see comment]. JAMA. 2005;287:455-63.

28. Hodgins DC, El-Guebaly N. Natural and treatment-assisted recovery from gambling problems: a comparison of resolved and active gamblers. Addiction. 2000;95:777-89.

29. Echeburua E, Baez C, Fernandez-Montalvo L. Comparative effectiveness of three therapeutic modalities in the psychological treatment of pathological gambling: long-term outcome. Behav Cogn Psychotherapy. 1996;24(1):51-72.

30. Ledgerwood DM, Petry NM. What do we know about relapse in pathological gambling? Clin Psych Rev. 2006;26:216-28.

31. Lesieur HR, Blume SB. The South Oaks Gambling Screen (SOGS): a new instrument for the identification of pathological gamblers. Am J Psych. 1987;144:1184-8.

32. Christenson GA, Faber RJ, deZwaan M. Compulsive buying: descriptive characteristics and psychiatric comorbidity. J Clin Psych. 1994;55:5-11. 